\title{
Vineyard pruning residues pellets for use in domestic appliances: a quality assessment according to the EN ISO 17225
}

\author{
Michela Zanetti, ${ }^{1}$ Benoît Brandelet, ${ }^{2}$ Diletta Marini, ${ }^{1}$ Andrea Sgarbossa, ${ }^{1}$ Chiara Giorio,, 3 \\ Denis Badocco, ${ }^{3}$ Andrea Tapparo, ${ }^{3}$ Stefano Grigolato, ${ }^{1}$ Caroline Rogaume, ${ }^{2}$ Yann Rogaume, ${ }^{2}$ \\ Raffaele Cavalli ${ }^{1}$
}

${ }^{1}$ Department of Land, Environment, Agriculture and Forestry, University of Padova, Legnaro (PD), Italy; ${ }^{2}$ Laboratory of Studies and Research on Wood Material, University of Lorraine, Épinal, France; ${ }^{3}$ Department of Chemical Sciences, University of Padova, Padova, Italy; ${ }^{4}$ Department of Chemistry, University of Cambridge, Cambridge, UK

\begin{abstract}
Nowadays many types of biomass are studied to satisfy the increased demand of renewable energy based on pellet combustion. However, only a few biomasses fulfil the high quality standard required for pellet used in domestic appliances. European and International standards in force define this quality of non-industrial use of pellets in term of the origin of biomass, physical, mechanical and chemical parameters. Vineyard residues are a worldwide potential source of energy but their compliance to be used in domestic pellet stoves has not been yet proven according to the new standards in force. In order to meet this need, this study makes an exhaustive characterisation of vineyard based pellets manufactured from residues of Prosecco (Glera variety) vineyards, assessing both the quality of biofuel and its behaviour dur-
\end{abstract}

Correspondence: Michela Zanetti, Department of Land, Environment, Agriculture and Forestry, University of Padova, viale dell'Università 16, 35020 Legnaro (PD), Italy.

Tel.: +39.049.8272726 - Fax: +39.049.8272750.

E-mail: michela.zanetti@unipd.it

Key words: Pellet; vineyard residues; stove combustion.

Acknowledgements: the study was carried out in the frame of the 'PRO.S.E.C.CO.' (Sustainable Production of Energy from Combustion and Compost - Rural Development Program (PSR) 2007-2013, Measure 124 - Veneto Region DGR 745 March 15, 2010) and 'Qualitative and quantitative study of polluting emissions linked to different types of biofuel from agricultural and forestry raw materials' (F.S.E. Grant No. 2105/1/30/1739/2011) projects.

Contributions: the authors contributed equally.

Conflict of interest: the authors declare no potential conflict of interest.

Received for publication: 13 October 2016.

Accepted for publication: 12 January 2017.

(C) Copyright M. Zanetti et al., 2017

Licensee PAGEPress, Italy

Journal of Agricultural Engineering 2017; XLVIII:612

doi:10.4081/jae.2017.612

This article is distributed under the terms of the Creative Commons Attribution Noncommercial License (by-nc 4.0) which permits any noncommercial use, distribution, and reproduction in any medium, provided the original author(s) and source are credited. ing combustion in a domestic pellet stove. The quality of biofuel has been evaluated according to the in force standards for wood and non-woody pellets. The results show that vineyard pellets do not meet the type B quality standards required for non-industrial use of wood pellet mainly because of the high amount of ash content $(>2 \%)$ and the high amount of copper $(>10 \mathrm{ppm})$ but they fulfil the specifications of the type $B$ non-woody pellets. Furthermore, during combustion test of vineyard-based pellet the high emission of $\mathrm{CO}$ indicates incomplete combustion; and vineyard-based pellet $\mathrm{NO}_{\mathrm{x}}$ emissions are more than double compared to those obtained during the control tests, confirming that the analysed vineyard-based pellets are unsuitable, as they are, for use in traditional pellet stoves.

\section{Introduction}

The world energy demand is increasing very fast as a consequence of economic growth and development. The global total primary energy supply more than doubled between 1971 and 2011 (IEA, 2015) and is expected to increase at higher rates in the next decades. The consequence of this growth is a progressive depletion of fossil resources and an availability of conventional oil and natural gas geographically restricted (Bentley et al., 2007; Hanlon and McCartney, 2008). Therefore, the use of renewable resources as an energy source is considered to be crucial. The demand of renewable energy goes on rising and the European REN21 2013 Global Status Report gives an estimated supplying of global final energy consumption from renewable sources of about $19 \%$ in 2011 and 2012 (Mcginn et al., 2013). Among different sources of renewable energy, biomass represents one of the most promising energy source. While wind and solar power depend on weather and seasonal changes, biomass can be stored and used when needed (Dunnet and Shah, 2007). Particularly, the production and use of woody biofuels can contribute to the overall greenhouse gases reduction due to their close-to-neutral carbon emission (Pierobon et al., 2015). Between solid biofuel, the pellets show the best technological properties because of their high density (more than 1000 $\mathrm{kg} \cdot \mathrm{m}^{-3}$ solid), their high bulk density (more than $500 \mathrm{~kg} \cdot \mathrm{m}^{-3}$ loose), their low moisture content (less than 10\%) and, as a consequence, their higher calorific value per volume unit compared to other traditional woody fuels (Dhamodaran and Afzal, 2012). These properties allow them to be burned with high combustion efficiency and to be used in a large variety of heating appliances with high conversion efficiency. Moreover, compared with other renewable sources, the level of technology required to exploit 
wood pellets is lower and less expensive (Sgarbossa et al., 2015). Furthermore, their regular shape and small dimensions allow storing and handling them like a fluid (Stelte et al., 2012). The quality of the pellets is important to ensure the combustion performance. To guarantee this performance the European and international standards fix reference values to be observed such as: bulk density, moisture content, mechanical durability, calorific value, chemical content and so on.

The pellet market in the European Union (EU) has shown a continuous expansion over the years. Europe produced 13.5 million of tons in 2014 amounting to around $50 \%$ of the global world production. The pellet production increased of 35\% from 2010 to 2014 and of $11 \%$ from 2013 to 2014. In the same period, EU was responsible for around $74.4 \%$ of the world's wood pellet consumption that increased up to 18.8 million tons consumed in 2014 (AEBIOM, 2015). Moreover, biomaterial for energy purposes could be produced or exploited almost worldwide by planning and adapting forest operations and agricultural management properly. The availability of data concerning the importation of pellet in EU is anyway limited to some estimations highlighting the significant importation from the USA (from 1.5 to 5.2 Mt between 2012 and 2015) (Dwivedi et al., 2014) as well the prediction of the growth of the global pellet production capacity (up to 46 million tons by 2020) (Pöyry, 2011).

It is clear that the traditionally used woody raw materials are not enough to meet the future needs (Stelte et al., 2012) without importing pellets, and different studies have shown an increasing interest towards alternative biomass (Carone et al., 2011; Saidur et al., 2011; Chico-Santamarta et al., 2012; Lehman et al., 2012; Verma et al., 2012; Carvalho et al., 2013; Cherney and Verma, 2013; Liu et al., 2014; Nunes et al., 2014). Agricultural by-products such as straw, pruning residues and other agricultural residues are a promising low-cost resource for pellet production (Mediavilla et al., 2009; Carone et al., 2011; Miranda et al., 2011; Chico-Santamarta et al., 2012; Liu et al., 2014). Among other biomass, vineyard-pruning residues represent a potential worldwide source of energy (Spinelli et al., 2012; Picchi et al., 2013). In Italy, according to the national census on Agriculture (Regione Veneto, 2012; ISTAT, 2014), vineyard area covers 664,296 ha. By considering an average value of 1.5 ton of dried vineyard residual per hectare (Velázquez-Martí et al., 2011) the potential availability in Italy can be estimated in approximately $1 \mathrm{Mt}$.

The few studies carried out on vineyards residues show con- trasting results: on the one hand they indicate that the vineyard residues are unsuitable for domestic use because of their relatively high moisture content and the frequent presence of oversized and/or undersized particles (Spinelli et al., 2012). On the other hand Picchi et al. (2013) showed in a preliminary study that, when the vineyard biomass is converted to pellets, they are suitable fuel for combustion in small-scale boilers, being their flue gas emissions comparable to those obtained from wood chips. With respect to these previous studies, substantial novelties have been introduced in this study. First of all, only one of these studies considered the pellets and made combustion tests (Picchi et al., 2013). In addition to this, the physico-mechanical characterisation of pellets focused only on few parameters and the elemental analysis did not take into account some of the mandatory elements included in the in force standards (Picchi et al., 2013). Crucially here, the first exhaustive characterisation of vineyard residues pellets according to the current EN ISO biofuel standard has been performed, characterisation that has been only partially done until now. Although the analysis according to the legislation is still voluntary, it is very important to carry out the analysis according to the standards because raw materials properties affect pellets quality as soon as their constituents are found nearly unchanged in the final product (Gil et al., 2010: Sgarbossa et al., 2014). The quality of pellet is directly related to their physical, mechanical and chemical properties (García-Maraver et al., 2011). These properties are influenced by different factors among which the origin of the biomass, thus, when analysing a solid biofuel according to the guidelines defined in the standards, it is essential to consider it. In the general requirement for solid biofuel EN ISO 17225-1:2014 the vineyard residues are referred as woody biomass and identified with origin number 1.1.7: Segregated wood from gardens, parks, roadside maintenance, vineyards, fruit orchards and driftwood from freshwater. The woody biomass 1.1.7 is contemplated in the origin sets by the specific standards for a type B pellet (ISO, 2014b).

In this framework, the aim of this study is to investigate for the first time the possibility of use vineyard pruning residues to produce type B pellets for non-industrial use as defined by the in force international ISO standard. In addition, some comparison have been made with the requirements of the standard EN ISO 172256:2014 for non-woody pellets (ISO, 2014c). The limit values contained in Table 1 - Specification of pellets produced from herbaceous biomass, fruit biomass, aquatic biomass and blends and mixtures of ISO 17225-6:2014 have been used for the comparison.

Table 1. Physico-mechanical characteristics of pellets according to in force standards.

\begin{tabular}{|c|c|c|c|c|c|c|c|c|c|c|}
\hline \multirow[b]{2}{*}{ Characteristics } & \multirow[b]{2}{*}{ Unit } & \multirow{2}{*}{$\begin{array}{l}\text { Wood pellet } \\
\text { Spruce }\end{array}$} & \multicolumn{3}{|c|}{ Vineyard residues pellet } & \multicolumn{3}{|c|}{ ISO 17225-2:2014 } & \multicolumn{2}{|c|}{ ISO 17225-6:2014* } \\
\hline & & & OVP & CVP & Blend & A1 & A2 & B & A & B \\
\hline \multirow[t]{2}{*}{ Bulk density } & $\mathrm{kg} \cdot \mathrm{m}^{-3}$ & 716.0 & 738.7 & 722.6 & 725.3 & \multirow[t]{2}{*}{$\geq 600$} & \multirow[t]{2}{*}{$\geq 600$} & \multirow[t]{2}{*}{$\geq 600$} & \multirow[t]{2}{*}{$\geq 600$} & \multirow{2}{*}{$\geq 600$} \\
\hline & SD & 2.19 & 6.24 & 7.24 & 5.96 & & & & & \\
\hline Moisture content & $\begin{array}{l}\text { W- } \% \text { dry } \\
\text { SD }\end{array}$ & $\begin{array}{l}7.0 \\
0.07\end{array}$ & $\begin{array}{l}6.3 \\
0.03\end{array}$ & $\begin{array}{l}8.1 \\
0.03\end{array}$ & $\begin{array}{l}7.2 \\
0.01\end{array}$ & $\leq 10$ & $\leq 10$ & $\leq 10$ & $\leq 12$ & $\leq 15$ \\
\hline \multirow[t]{2}{*}{ Ash } & $\mathrm{w}-\%$ dry & 0.4 & 3.3 & 5.5 & 4.2 & \multirow[t]{2}{*}{$\leq 0.7$} & \multirow[t]{2}{*}{$\leq 1.2$} & \multirow[t]{2}{*}{$\leq 2.0$} & \multirow[t]{2}{*}{$\leq 6$} & \multirow[t]{2}{*}{$\leq 10$} \\
\hline & SD & 0.02 & 0.03 & 0.13 & 0.12 & & & & & \\
\hline Low calorific value & $\begin{array}{l}\text { MJ.kg-1 } \\
\text { SD }\end{array}$ & $\begin{array}{l}17.3 \\
0.01\end{array}$ & $\begin{array}{l}16.7 \\
0.03\end{array}$ & $\begin{array}{l}16.3 \\
0.04\end{array}$ & $\begin{array}{l}16.5 \\
0.01\end{array}$ & $Q \geq 16.5$ & $Q \geq 16.5$ & $Q \geq 16.5$ & $Q \geq 14.5$ & $Q \geq 14.5$ \\
\hline Durability & $\begin{array}{l}\% \\
\text { SD }\end{array}$ & $\begin{array}{l}99.2 \\
0.02 \\
\end{array}$ & $\begin{array}{l}98.1 \\
0.05 \\
\end{array}$ & $\begin{array}{l}97.4 \\
0.10 \\
\end{array}$ & $\begin{array}{l}96.0 \\
0.05 \\
\end{array}$ & $\geq 97.5$ & $\geq 97.5$ & $\geq 96.5$ & $\geq 97.5$ & $\geq 96.0$ \\
\hline
\end{tabular}

OVP, organic vineyard pellets; CVP, common vineyard pellets; Blend, 50\% of OVP and 50\% CVP; SD, standard deviation. * Source: Table 1 - Specification of pellets produced from herbaceous biomass, fruit biomass, aquatic biomass and blends and mixtures of ISO 17225-6:2014. (Note: Blends and mixtures include blends and mixtures from the main origin-based solid biofuel groups 1 to 4 (Table 1 - Classification of origin and sources of solid biofuels of ISO 17225-1:2014). The SD values are in italics to distinguish them from values of the parameters used for classification. 
In fact, the Blends and mixtures biomass origin include blends and mixtures from the main origin-based solid biofuel groups 1 to 4 of Table 1 - Classification of origin and sources of solid biofuels of ISO 17225-1:2014 (ISO, 2014a).

To reach this objective the following analysis have been carried out: i) physico-mechanical and element characterisations of three types of vineyard residues pellet following the European and International standards; ii) characterisation of combustion emissions using a pellet stove; iii) comparison of measured technical performance with a commercial wood-based pellet to understand the potential use of the vineyard residues pellets.

\section{Materials and methods}

\section{Pellet manufacturing}

Four different types of pellet were used in this study: one commercial wood-based pellet (spruce, Picea abies (L.) Karst.) and three made from Glera variety vineyard pruning residues. The samples were collected in form of woodchips from two heaps obtained by the chipping of the vineyard residues from an organic grown vineyard and a commonly managed vineyard, both located in the Prosecco vineyard area (Treviso Province, North-Eastern Italy). The vineyard residues were collected and chipped by the same shredder machine (Peruzzo Cobra Collina, Curtarolo, Italy). The vineyard residues chips were stored for 8 months before converting them into pellets.

Before the pelletizing, the vineyard chips were reduced in dimension by grinding them through a hammer mill (sieve apertures $4 \mathrm{~mm}$ ). Then, each material has been dried to $12 \%$ and was then pelletized using a $20 \mathrm{~kW}$ CLM200 La Meccanica srl (Padova, Italy) pelletiser. No additives were used for the pellets production. Three types of pellets have been obtained: organic grown vineyard residues pellet (OVP), commonly managed vineyard residues pellet (CVP) and pellet blend (Blend).

The pellet blend was made by mixing up $50 \%$ of organic grown vineyard residues and $50 \%$ of commonly managed vineyard residues. The vineyard residues pellets were compared with a commercial pellet. The commercial pellets often satisfy the stricter pellet requirements: A1 or A2 (Table 1 - Specification of wood pellets for non-industrial use; ISO 2014b). In this study, spruce (Picea abies $L$.) wood pellet produced in Italy has been used as a reference as it is by far one the most widely used pellet fuel used in Italy and, generally, in Europe.

\section{Pellet characterisation}

\section{Physico-mechanical characterisation}

Pellet characteristics were assessed according to the current European standards because, in the period in which the study was carried out (2011-2012), ISO standards relating to methods of analysis were not yet entered into force. However, the methods of analysis described in the new ISO standards are the same as those reported in the no longer in force European standards. The physico-mechanical properties required for the standard classification are: moisture content, bulk density, durability, fines, ash content and net calorific value. The ash melting behaviour is another physical parameter taken into account in the pellet classification but since the standard (ISO, 2014b) does not indicate limit values, this measure has not been considered in the classification.

The moisture content on a wet basis, as received, was deter- mined according to the UNI EN 14474-1:2009 (UNI, 2009a).

The bulk density was measured following the UNI EN 15103:2009 (UNI, 2009c), using a steel container of a filling volume of $5 \mathrm{~L}$. Results are reported as the average of three replications.

The mechanical durability test was performed following the indications of UNI EN 15210-1:2009 (UNI, 2009d). The standard (UNI, 2009d) indicates also how to measure the fines content. The amount of dust and fines is correlated with the mechanical properties of the pellet and describes its tendency to disintegrate under stress. The fines in the bag are strictly related to the specific treatment that the bag underwent (i.e., transportation, storage, handling) (Sgarbossa et al., 2014). While it is particularly important for commercial bag pellets, it is meaningless in case of experimental pellets and for this reason it was not taken into account in this study. To measure the ash content (A), the calorific value (Q) and the element content of pellets, a representative subsample (UNI, 2011a) of each pellet was ground using a laboratory-cutting mill to reduce the particle size distribution to a nominal top size of $1 \mathrm{~mm}$. The ash content (A) was assessed according to the UNI EN 14775:2010 (UNI, 2010). The reported results are the average of the three replications on a wet basis (as received) given the moisture content of the sample being incinerated.

The indications of UNI EN 14918:2009 (UNI, 2009b) were followed to measure calorific value (Net calorific value - Q) using a IKA C-200 calorimeter that gives the high heating value as received. The average of three replications was calculated.

The amount and type of additives have also to be stated. In this study, no additives have been added during or after the vineyardbased pellet production and in the control pellet.

\section{Elemental characterisation}

The ISO methodology for elemental characterisation is available but, for consistency between the standard experimental methods, the UNI EN standards have been adopted.

The heavy metal content of pellet was measured according to the UNI EN 15297:2011 (UNI, 2011f). For the determination of arsenic (As), cadmium (Cd), cobalt (Co), chromium (Cr), copper $(\mathrm{Cu})$, mercury $(\mathrm{Hg})$, manganese $(\mathrm{Mn})$, molybdenum (Mo), nickel $(\mathrm{Ni})$, lead $(\mathrm{Pb})$, vanadium $(\mathrm{V})$ and zinc $(\mathrm{Zn}), 0.3 \mathrm{~g}$ of grounded pellet were treated with $3 \mathrm{~g}$ of nitric acid $(67 \%)$ in a CEM Discover SP-D (CEM Corp., Matthews, NC, USA) microwave digester (from $20^{\circ} \mathrm{C}$ to $200^{\circ} \mathrm{C}$ at $400 \mathrm{psi}$ in $4 \mathrm{~min}, 2 \mathrm{~min}$ at this final condition). Preliminary tests showed that clear solutions could be obtained without addition of hydrogen peroxide and hydrofluoric acid. After digestion, solutions were diluted in a $50 \mathrm{~mL}$ volumetric flask with milliQ water and analysed by ICP-MS (Agilent 7700x; Agilent Technologies, Santa Clara, CA, USA). Measurement uncertainty was lower than 5\%, other analytical details are reported in Badocco et al. (2015). Using a similar procedure (UNI, 2011e), lithium ( $\mathrm{Li})$, beryllium $(\mathrm{Be})$, boron $(\mathrm{B})$, magnesium $(\mathrm{Mg})$, aluminum $(\mathrm{Al})$, potassium $(\mathrm{K})$, calcium $(\mathrm{Ca})$, iron $(\mathrm{Fe})$, gallium $(\mathrm{Ga})$, selenium (Se), rubidium (Rb), strontium (Sr), silver (Ag), tellurium $(\mathrm{Te})$, barium $(\mathrm{Ba})$ and thallium $(\mathrm{Tl})$ were also determined. This complementary but not mandatory analysis has been done to determine a possible chemical contamination by pesticide residues and other contaminant agents in order to complete the quality assessment of the pellets.

A CHNS elemental analyser (Thermo Scientific mod. Flash 2000; Sigma-Aldrich Co., Saint Louis, MO, USA) was used for the determination of nitrogen and sulphur content following the method UNI EN 15104:2011 (UNI, 2011c). Chlorine content was determined by UNI EN 15289:2011 (UNI, 2011d) procedure using 
a calorimetric bomb and ion chromatographic analysis of chloride. The concentration of nitrate and sulphate also determined by ion chromatography were in agreement with CHNS results.

Since the goal of this study is the fuel assessment following the standard, all the physico-mechanical properties and elemental content of pellets are compared with the limits set by the standards in force. The pellets have been classified following the new requirements defined by EN ISO 17225-2:2014 (ISO, 2014b) and EN ISO 17225-6:2014 (ISO, 2014c).

\section{Combustion}

The combustion tests have been realised on a classic pellet stove of $8 \mathrm{~kW}$ of 2007 following the European norm UNI EN 14785:2006 (UNI, 2006). The stove is separated from the chimney by a water seal in order to be able to weight the pellet consumption, as the appliance is placed on a weighing scale. An extractor regulated the flue draught at $12 \mathrm{~Pa}$. The pellet stove is supplied automatically and continuously until the room temperature set point has been reached. In order to avoid any interruption in the pellet supply, the room temperature set point was defined to $35^{\circ} \mathrm{C}$. At the beginning of each experiment, observations and optimisation of the combustion were achieved through airflow settings in order to minimise the $\mathrm{CO}$ emissions for each type of pellets.

The combustion test is composed in 4 steps: i) observation and optimisation of the combustion; ii) sampling of total suspended particles (TSP) $(1 \mathrm{~h})$; iii) sampling of particulate matter (PM) in mass with a manual impactor (1 h); iv) sampling of particulate matter in number with an electrical low pressure impactor $(1 \mathrm{~h})$.

During these four steps, different parameters were measured continuously: i) physico-chemical properties of the smoke with photochemical cells $\left(\mathrm{O}_{2}, \mathrm{CO}, \mathrm{NO}_{\mathrm{x}}\right.$, temperature of the smoke, ambient temperature); ii) consumption of pellet with the balance; iii) solid particles emissions with an optical analyser on the duct.

Quartz filter have been used to sample TSP and PM in mass. Filter has been put in a stove at $180^{\circ} \mathrm{C}$ during $4 \mathrm{~h}$, in a desiccator during $4 \mathrm{~h}$ and weighted. The weight process is the same for the initial mass than for the final. For both these samplings, the filter and all the line were heated at $160^{\circ} \mathrm{C}$. The flow of smoke was $101 \mathrm{~min}^{-1}$ to get a speed of $1 \mathrm{~m} \mathrm{~s}^{-1}$ in the nozzle and thus to be isokinetic.

\section{Results and discussion}

\section{Pellet characterisation}

\section{Physico-mechanical characterisation}

As reported in Table 1, most of the physical characteristics of vineyard pellet are similar to that of wood pellet for non-industrial use and the values are within the standard limits. The main difference is the ash content that in the vineyard pellet is up to 13 times higher than in woody pellet (CVP: $5.51 \%$ instead of $0.41 \%$ of spruce pellet), and almost double the limit set by the standard for a type B pellet $(\leq 2.0 \%)$, but it is within the standard limit defined in the standard for a type A non-woody pellets $(\leq 6.0 \%$; ISO, 2014c). A higher ash content of vineyard pellet compared to wood pellet has been found also by Picchi et al. (2013) but the difference between values is not so marked as in this study since the vineyard residues pellet showed an ash content of $2.1 \%$. This variability could be related to the vineyard residual biomass variety, the location of harvested area and other parameters that could influence the quality of biomass (Vassilev et al., 2010).
Pellet durability is one of the most important pellet parameters because a high share of fines increases dust emissions during combustion and can cause failure in the feeding system (Obernberger and Thek, 2004). The durability of the wood pellets and the CVP and OVP largely satisfy the standard for a type B pellet but not the blend pellet that shows a durability of $96 \%, 0.5 \%$ less than the value set for a type B pellet $(96.5 \%)$ but still in line with the limit imposed for type B non-woody pellets (96\%; ISO, 2014c). Considered the OVP and CVP durability value, this value seems to be influenced mainly by the CVP pellet durability that is lower than the OVP one. In order to improve the pellet durability, the standards authorise the addition of small amounts $(\leq 2 \%)$ of biological binding agents (Obernberger and Thek, 2004; Kaliyan and Morey, 2009; Hu et al., 2015). Moisture contained in the biomass also acts as a binding agent in the pelleting process. A positive correlation between the moisture content of raw materials and pellet durability has been found by Lehtikangas (2001).

Mechanical durability and bulk density are the pellet quality parameters that can be optimised in the pelletizing process (Larsson and Rudolfsson, 2012). Adapting the pelletizing temperatures and pressure to the vineyard residues production could influence positively the durability of pellets. Since the goal of this study was not the improvement of the vineyard residues based pellets characteristics, those process optimisations were not included in the study and were not investigated.

The net calorific value, the moisture content and the OVP pellet durability values are within the limits set by the existing standard. The average calorific value of spruce pellet, OVP, and Blend are 17.3 MJ.kg-1, 16.7 MJ.kg-1, and 16.5 MJ.kg-1 respectively. The calorific value of CVP (16.3 MJ. $\mathrm{kg}^{-1}$ ) does not satisfy the requirement of International standard for wood pellet (ISO, 2014b) but satisfies the standard for non-woody pellets (ISO, 2014c) where the limit is set at $14.5 \mathrm{MJ}_{\mathrm{kg}}{ }^{-1}$. Taking into account the moisture content, these results show the same trend than those found in the literature about vineyard biomass (Picchi et al., 2013).

Considering the physical and mechanical characterisation, the vineyard residues pellets are not able to satisfy the specifications for a non-industrial use set by the in force standards mainly because of the high ash content and the low durability (pellet Blend). If the OVP approached the type B standard limit set by the no longer in force UNI EN 14961-2:2011 (UNI, 2011b), surpassing it by only $0.3 \%$ the ash content set by the standard (3\%), it is now far from meeting the stricter limit of $2 \%$ defined by the EN ISO 17225-2:2014 (ISO, 2014b). Mixing vineyard residues with virgin wood biomass could help to reduce this value within the standard limits. In the other hand, the characteristics of the vineyard residues pellets meet the requirements of ISO standard for the type B non-woody pellets.

\section{Elemental characterisation}

To attest the quality of pellet, the element analysis is mandatory. The elements in biomass can be classified as major $(>1 \%)$, minor $(0.1-1.0 \%)$ and trace $(<0.1 \%)$ elements according to their concentrations (dry basis) (Vassilev et al., 2010). In decreasing order of abundance, the elements in biomass are commonly carbon (C), oxygen $(\mathrm{O})$, hydrogen $(\mathrm{H})$, nitrogen $(\mathrm{N}), \mathrm{Ca}, \mathrm{K}$, silicon $(\mathrm{Si})$, $\mathrm{Mg}, \mathrm{Al}$, sulphur (S), Fe, P, chlorine (Cl), sodium (Na), Mn and titanium (Ti) (Vassilev et al., 2010). Some element concentrations in a fuel can be used to predict ash-forming matter in biomass combustion systems (Werkelin et al., 2010) and can form gaseous and solid compounds, as it will be discussed later. The main ash forming elements are $\mathrm{Si}, \mathrm{Al}, \mathrm{Fe}, \mathrm{Ca}, \mathrm{Mg}, \mathrm{Mn}, \mathrm{Na}, \mathrm{K}, \mathrm{P}, \mathrm{S}$ and $\mathrm{Cl}$ (Werkelin et al., 2010). Tables 2 and 3 reported the elementary 
characterisation of vineyard residues pellets and wood pellets.

\section{Mandatory elements included in the ISO 17225-2 standard}

The elements that are mandatory for the EN ISO standard characterisation are: $\mathrm{N}, \mathrm{S}, \mathrm{Cl}, \mathrm{Cr}, \mathrm{Ni}, \mathrm{Cu}, \mathrm{Zn}, \mathrm{As}, \mathrm{Cd}, \mathrm{Pb}$ and $\mathrm{Hg}$ (Table 2). As far as the elements included in the standard EN ISO 172252:2014 (ISO, 2014b) are taken into account, all the vineyard residues pellets do not satisfy the standard requirements for the higher amount of $\mathrm{Cu}(>10 \mathrm{ppm})$ (Table 2). Instead, they satisfy the $\mathrm{Cu}$ limit set by the standard for non-woody pellet that is $20 \mathrm{ppm}$.
The highest $\mathrm{Cu}$ content is shown by the pellet from the organic grown vineyard. This result is not surprising because $\mathrm{Cu}$ is one of the most important biopesticides used in organic farms as a fungicide, bactericide and also herbicide (Provenzano et al., 2010; Tariba, 2011). Moreover, the OVP stacks were covered therefore the $\mathrm{Cu}$ leaching was reduced. High amounts of $\mathrm{Cu}$ in the vineyard residues pellets have been found also by Picchi et al. (2013) but with an inverse trend: the commonly managed vineyards pellet had a higher amount of $\mathrm{Cu}$ compared to the organic one. This difference could be due to the type of vineyards, the frequency and

Table 2. Element content of pellets according to the in force standards.

\begin{tabular}{|c|c|c|c|c|c|c|c|c|c|c|}
\hline & & Wood pellet & Vin & residue & let & IS & 7225-2 & 014 & ISO & \\
\hline Elements & Unit & Spruce & OVP & CVP & Blend & A1 & A2 & B & A & B \\
\hline Chlorine & w-\% dry & 0.0040 & 0.008 & 0.0041 & 0.0064 & $\leq 0.02$ & $\leq 0.02$ & $\leq 0.03$ & $\leq 0.10$ & $\leq 0.30$ \\
\hline Nitrogen & w-\% dry & 0.090 & 0.56 & 0.64 & 0.61 & $\leq 0.3$ & $\leq 0.5$ & $\leq 1.0$ & $\leq 1.5$ & $\leq 2.0$ \\
\hline Sulphur & w-\% dry & 0.010 & 0.030 & 0.048 & 0.038 & $\leq 0.04$ & $\leq 0.04$ & $\leq 0.05$ & $\leq 0.20$ & $\leq 0.30$ \\
\hline Arsenic & ppm dry & $<0.03$ & 0.16 & 0.34 & 0.22 & $\leq 1$ & $\leq 1$ & $\leq 1$ & $\leq 1$ & $\leq 1$ \\
\hline Cadmium & ppm dry & 0.16 & 0.17 & $<0.03$ & 0.04 & $\leq 0.5$ & $\leq 0.5$ & $\leq 0.5$ & $\leq 0.5$ & $\leq 0.5$ \\
\hline Chromium & ppm dry & 0.1 & 1.00 & 4.4 & 2.8 & $\leq 10$ & $\leq 10$ & $\leq 10$ & $\leq 50$ & $\leq 50$ \\
\hline Copper & ppm dry & 0.78 & 16.3 & 13.1 & 12.9 & $\leq 10$ & $\leq 10$ & $\leq 10$ & $\leq 20$ & $\leq 20$ \\
\hline Lead & ppm dry & 0.070 & 0.37 & 0.70 & 0.34 & $\leq 10$ & $\leq 10$ & $\leq 10$ & $\leq 10$ & $\leq 10$ \\
\hline Mercury & ppm dry & $<0.001$ & $<0.001$ & $<0.001$ & $<0.001$ & $\leq 0.1$ & $\leq 0.1$ & $\leq 0.1$ & $\leq 0.1$ & $\leq 0.1$ \\
\hline Nickel & ppm dry & 0.110 & 0.80 & 1.69 & 1.24 & $\leq 10$ & $\leq 10$ & $\leq 10$ & $\leq 10$ & $\leq 10$ \\
\hline Zinc & ppm dry & 31 & 47 & 43 & 44 & $\leq 100$ & $\leq 100$ & $\leq 100$ & $\leq 100$ & $\leq 100$ \\
\hline
\end{tabular}

OVP, organic vineyard pellets; CVP, common vineyard pellets; Blend, 50\% of OVP and 50\% CVP. *Source: Table 1 - Specification of pellets produced from herbaceous biomass, fruit biomass, aquatic biomass and blends and mixtures of ISO 17225-6:2014. (Note: Blends and mixtures include blends and mixtures from the main origin-based solid biofuel groups 1 to 4 (Table 1 - Classification of origin and sources of solid biofuels of ISO 17225-1:2014).

Table 3. Complementary mineral element characterisation of pellets.

\begin{tabular}{|c|c|c|c|c|c|c|c|c|}
\hline \multirow{3}{*}{ Elements } & \multirow{3}{*}{ Unit } & \multirow{3}{*}{$\begin{array}{l}\text { Wood pellet } \\
\text { Spruce }\end{array}$} & \multicolumn{3}{|c|}{ Vineyard residues pellet } & \multicolumn{2}{|c|}{ Typical variation value } & \multirow{3}{*}{$\begin{array}{l}\text { ISO } 17225-1^{\circ} \\
\text { Grass, in general }\end{array}$} \\
\hline & & & OVP & CVP & Blend & ISO 1 & $225-1 *$ & \\
\hline & & & & & & Coniferous wood & Broad-leaf wood & \\
\hline Aluminium & ppm dry & 16.8 & 67 & 320 & 210 & 30 to 400 & $<10$ to 50 & 20 to 300 \\
\hline Barium & ppm dry & 3.2 & 8.2 & 3.7 & 4.3 & na & na & na \\
\hline Beryllium & ppm dry & $<0.03$ & 1.25 & $<0.03$ & $<0.03$ & na & na & na \\
\hline Boron & ppm dry & 7.9 & 33 & 26 & 23 & na & na & na \\
\hline Calcium & ppm dry & 870 & 6100 & 7100 & 7300 & 500 to 1000 & 800 to 20000 & 2500 to 5500 \\
\hline Cobalt & ppm dry & $<0.03$ & 0.150 & 0.130 & 0.090 & na & na & na \\
\hline Gallium & ppm dry & $<0.03$ & 1.44 & 0.66 & 0.72 & na & na & na \\
\hline Iron & ppm dry & 9.0 & 68 & 330 & 200 & 10 to 100 & 10 to 100 & 100 to 1200 \\
\hline Lithium & ppm dry & 0.46 & 0.69 & 0.42 & 0.48 & na & na & na \\
\hline Magnesium & ppm dry & 187 & 1360 & 1520 & 1530 & 100 to 200 & 100 to 400 & 800 to 2300 \\
\hline Manganese & ppm dry & 84 & 27 & 28 & 28 & 40 to 200 & na & 200 to 2600 \\
\hline Molybdenum & ppm dry & $<0.03$ & 0.22 & 0.30 & 0.21 & na & na & na \\
\hline Potassium & ppm dry & 340 & 4400 & 5000 & 4900 & 200 to 500 & 500 to 1500 & 4900 to 24000 \\
\hline Rubidium & ppm dry & 1.62 & 2.9 & 1.37 & 1.76 & na & na & na \\
\hline Selenium & ppm dry & $<0.03$ & 1.85 & 0.26 & $<0.03$ & na & na & na \\
\hline Silver & ppm dry & 0.050 & 0.39 & 0.070 & 0.050 & na & na & na \\
\hline Strontium & ppm dry & 2.9 & 7.6 & 16.1 & 12.6 & na & na & na \\
\hline Tellurium & ppm dry & $<0.03$ & 0.25 & 0.040 & $<0.03$ & na & na & na \\
\hline Thallium & ppm dry & $<0.03$ & 0.140 & $<0.03$ & $<0.03$ & na & na & na \\
\hline Vanadium & ppm dry & $<0.03$ & 0.25 & 0.76 & 0.50 & $<2$ & $<2$ & Not specified \\
\hline
\end{tabular}

OVP, organic vineyard pellets; CVP, common vineyard pellets; Blend, 50\% of OVP and 50\% CVP; na, not available. *Source: Table B.1 - Typical values for virgin wood materials, with or without insignificant amounts of bark, leaves and needles (EN ISO 17225-1:2014); ${ }^{\circ}$ Source: Table B.8 - Typical values for virgin grass in general (hay) and miscanthus (EN ISO 17225-1:2014). 
amount of fertiliser used (Kavargiris et al., 2009) and the biomass sampling method (Duca et al., 2016). As far as the CVP are concerned, the $\mathrm{S}$ content satisfies the limit set by the standard. The value of $0.05 \%$ is in the limit for a type B pellet $(\leq 0.05 \%)$ defined in the in force ISO 17225-2:2014 (ISO, 2014b). Considering the $\mathrm{N}$ value, the vineyard residues pellets show high $\mathrm{N}$ content, six to seven times higher than the spruce pellet but still within the limits set by the EN ISO standards ( $\leq 1.0$, type B pellet) (ISO 2014b). For biomass fuel, $\mathrm{N}$ as $\mathrm{S}$ and $\mathrm{Cl}$ are in focus because they cause gaseous emissions $\left(\mathrm{NO}_{\mathrm{x}}, \mathrm{SO}_{2}, \mathrm{HCl}\right)$. The fuel- $\mathrm{N}$ is almost converted to the gaseous phase during combustion, while $\mathrm{S}$ and $\mathrm{Cl}$ form gaseous and solid compounds (Obernberger et al., 1997, 2006). Furthermore, with $\mathrm{K}$ and $\mathrm{Na}$, they may form molten phases during combustion that make the ash particle to adhere to the heat transfer surfaces (Obernberger and Thek, 2004).

The CVP pellet contains more than four time of $\mathrm{Cr}$, twice of $\mathrm{Pb}$ and almost half of As compared to the OVP pellet, but in both of pellets these values are still satisfying the limits of standards $(\leq 10$ $\mathrm{ppm}$ ). The Blend pellets show the less content of $\mathrm{Pb}$ compared to the CVP and OVP pellets, while the amount the $\mathrm{Cr}$ correspond to the average of the CVP and OVP values (2.8 ppm dry). As expected, since wood has not been treated, the content of $\mathrm{Cr}$ and $\mathrm{Pb}$ of wood pellets are the lowest ones.

\section{Additional elemental characterisation}

In order to make an exhaustive analysis of pellets, additional elements content, not required by the regulations, has been investigated. The results are reported in Table 3.

Looking at the table, it becomes immediately evident that some mineral content of vineyard residues pellets is far higher than that of wood pellets. Particularly notable are the amounts of $\mathrm{B}, \mathrm{Mg}$, $\mathrm{Al}$ and $\mathrm{K}$. Generally, $\mathrm{Al}$ and $\mathrm{K}$ are contained in larger amounts in logging residues than in virgin wood. The typical variation content of $\mathrm{Al}$ in broad-leaf wood is from 1 up to $3000 \mathrm{ppm}$ and that of $\mathrm{K}$ is from 1000 up to 4000 ppm (Table B.3 of ISO 17225-1:2014; ISO, 2014b). However, vineyard residues K content is significantly higher than the typical variation values also when compared to logging residues but not when compared with other non-woody biomass (Table 3). Ca content is higher compared with wood pellet but it is included in the typical variation value of broad-leaf wood. The Fe content of the CVP and the Blend exceeds the value range indicated by the standard for virgin wood. It is respectively five and three times higher than OVP whose value is 7.5 times higher than the spruce pellet Fe contents but it is comprised in the typical variation value of a non-woody biomass.

Only the Mn content of spruce pellet is three times higher than that of vineyard residues pellets: $84 \mathrm{ppm}$ instead of $27-28 \mathrm{ppm}$. The high Mn content is characteristic of wood and woody biomass and it is negatively correlated to the amount of ash (Vassilev et al., 2010). Recently, Toscano et al. (2013) found that the correlations among $\mathrm{S}, \mathrm{Cl}, \mathrm{N}, \mathrm{K}, \mathrm{Na}$ and ash content are positive and significant, while $\mathrm{Mn}$ does not show any significant correlation. In particular, $\mathrm{S}$ and $\mathrm{K}$ are the most important elements linked to the ash content. These results are consistent with this study where to a high content of $\mathrm{S}, \mathrm{N}, \mathrm{Cl}$ and $\mathrm{K}$ corresponds greater ash content while the high $\mathrm{Mn}$ content of spruce pellet does not affect the amount of ash (Tables 1-3), which is lower than that of vineyard residues. The presence of ash-forming elements, like $\mathrm{Ca}$ or $\mathrm{K}$, in trees and other plants is the result of biochemical processes, the mineral uptake from soil and the elements transport within the tree or plants (Werkelin et al., 2010). The Mn content in grass is variable (Table 3). The comparison should be made using the value of single grass species. Table B.8 of ISO 17225-1:2014 (ISO, 2014a) shows that the typical value of Mn contained in Miscanthus sinensis (China reed) is $20 \mathrm{ppm}$ and it can vary from 10 to $100 \mathrm{ppm}$, then in a lesser extent compared to coniferous wood (Table 3). Environmental factors as growing conditions, harvesting time or pick-up of extraneous material also influence the amount and presence of ash-forming elements (Vassilev et al., 2010).

Comparing organic and commonly grown vineyard residues, generally CVP have higher element contents, but, in addition to the previously discussed $\mathrm{Cu}$, certain trace elements as $\mathrm{Ag}, \mathrm{B}, \mathrm{Be}, \mathrm{Ga}$, $\mathrm{Se}, \mathrm{Rb}, \mathrm{Te}, \mathrm{Ba}, \mathrm{Tl}$ (Table 3 ) are contained in higher quantities in the pellets resulting from organic vineyards than the pellets from commonly managed vineyards. Furthermore, it is evident that the OVP $\mathrm{Be}, \mathrm{Li}, \mathrm{Rb}, \mathrm{Ag}, \mathrm{Te}$ and $\mathrm{Tl}$ element contents is always higher than wood pellet contents while the elements content of CVP and Blend is not always higher than wood pellets. Indeed, the $\mathrm{Li}$ and $\mathrm{Rb}$ contents of CVP are contained in a lesser extent than in the wood.

In this study the differences between the organic and commonly managed vineyard pellets could be ascribed to the types and doses of fertiliser and pesticide used which influence the amounts of some elements as Cl, N, P, S (Obernberger et al., 1997; Picchi et al., 2013) and trace elements, to the growing conditions or to the vineyards distance from sources of pollution as heavy traffic roads or cities (Pastircakova, 2004).

In view of above, vineyard residues pellets seem to be difficult to burn properly because of the high amount of ashes due to the high amount of ash-forming elements as $\mathrm{Al}, \mathrm{Ca}, \mathrm{Mg}, \mathrm{K}, \mathrm{S}$ and $\mathrm{Cl}$. Therefore, for an exhaustive characterisation, the combustion behaviour and the analysis of emissions of pellets have been investigated.

\section{Pellet emissions characterisation}

\section{Combustion behaviour}

To have an exhaustive overview of vineyard-based pellet performance, a combustion analysis was carried out. Vineyard-based pellet combustion presented some important issues. The first one concerned not only the ash content, but also the ash physic. Vineyard based pellets showed an important ash content, but the real problem was its hardness, which implied that the ash filled the combustion chamber really fast because it kept the geometry of the pellet. The second issue was the excess of air. To burn these pellets, a lot of air was injected. It may be due to the higher density of vineyard-based pellet. At the same time, a lot of air means a colder combustion chamber (because five times of cold $\mathrm{N}_{2}$ is brought when $1 \mathrm{O}_{2}$ is brought) and then some higher pollutant emissions. All the tests of these pellets were shortened because the combustion stopped due to both troubles described above. Anyway, even if the experiments were shorter than $1 \mathrm{~h}$, a lot of data were produced and the results are reported in Tables 4 and 5. It is relevant in that case to emphasize that the emissions characterisation described below, especially those concerning CVP, will be strongly influenced by these poor combustion conditions. Therefore, the results concerning CVP should be considered with care.

\section{Emissions characterisation: physico-chemical properties of the smoke}

During a perfect combustion, the solid organic of a fuel part is completely oxidised into $\mathrm{CO}_{2}$ and $\mathrm{H}_{2} \mathrm{O}$ (Obernberger et al., 2006). To achieve an ideal combustion, the ratio between the amount of air added and the amount of air (oxygen) necessary for a complete combustion ( $\lambda$, excess of air) should be 1 . In practical, it is impossible to obtain this ratio. The typical value of $\lambda$ in domestic wood 
appliances is comprised between 2.43 (wood-stoves) and 3 (pellet stoves) (Van Loo and Koppejan, 2008). For the combustion technology used in this study, the $\lambda$ value was around 3 (comprising between 3 for spruce and $>4$ for vineyard residues pellet). Furthermore, the emission of CO (Table 4 and Figure 1A) was also an indication of incomplete combustion. OVP showed the highest emission of CO measured around $4530 \mathrm{ppm}$. The high emission value of CO detected in OVP influenced the value of CO emitted from Blend pellet combustion (3780 ppm). The formation of ash lumps and slag could also cause an uneven flow of combustion air, which influences the quality of combustion (Carvalho et al., 2013).

As reported in Table 2, nitrogen content of vineyard-based pellets was higher than the control one. Nitrogen content in the biomass is converted into gaseous $\mathrm{N}_{2}$ and nitric oxides $\left(\mathrm{NO}_{\mathrm{x}}\right)$ during the combustion. For temperatures lower than $1300^{\circ} \mathrm{C}$, the $\mathrm{N}$ emissions result from $\mathrm{N}$ content of fuel (Van Loo and Koppejan, 2008) and to higher $\mathrm{N}$ content in the biomass corresponds higher emissions of $\mathrm{NO}_{\mathrm{x}}$. $\mathrm{N}$ concentration $>0.6 \%$ in the fuel corresponds to emission related problems (Obernberger et al., 2006). As expected, the vineyard-based pellet $\mathrm{NO}_{\mathrm{x}}$ emissions were more than double the emission of the control one (Table 4). Between vineyard-based pellets, the CVP combustion emitted the highest quantity of $\mathrm{NO}_{\mathrm{x}}(218 \mathrm{ppm})$ while the Blend and OVP pellets were the less emissive, respectively 174 and 175 ppm (Table 4).

CVP showed the highest content of $\mathrm{N}(0.64 \%$; Table 2$)$, but the differences between vineyard-based pellets $\mathrm{N}$ content in the fuel do not justify the difference of $\mathrm{NO}_{\mathrm{x}}$ emissions measured. This result has been observed also by Carvalho et al. (2013) and it could be due to the high concentrations of $\mathrm{CO}$ that inhibit $\mathrm{NO}_{\mathrm{x}}$ formation, as observed for OVP and Blend, or to the catalytic effect of char and ash (Garijo et al., 2003). On the other hand, according to Dias et al. (2004), for highest concentration of $\mathrm{N}$ in the solid biofuel, the $\mathrm{NO}_{\mathrm{x}}$ emissions increase with the oxygen concentration in the flue gas (Table 4). But here, among the vineyard pellets, the smoke of CVP was the lowest in $\mathrm{O}_{2}$ (for vineyard pellet) but the more emissive in $\mathrm{NO}_{\mathrm{x}}$.

\section{Particulate characterisation: total suspended particles}

Table 5 and Figure 1B, C and D show the particulate (PM) characterisation using the pellet stove of the different types of pellets tested. Concerning TSP (Figure 1B), CVP looked the best and emitted few particles (44.4 mg. $\mathrm{Nm}^{-3}$ ). This low value of CVP was due to the really hard ashes that were formed in the combustion chamber which avoid the reaction of combustion. OVP was the biggest emitting pellet tested with $256 \mathrm{mg} \cdot \mathrm{Nm}^{-3}$ at $13 \% \mathrm{O}_{2}, 2.5$ more than the standard one. Anyway, CVP results should be considered with care as the combustion conditions were degraded due to the formation of hard ashes in the combustion chamber. It appears in that case that Blend was the best vineyard residues pellet with $210 \mathrm{mg} \cdot \mathrm{Nm}^{-3}$ at $13 \% \mathrm{O}_{2}$. The TSP emissions measured at almost $100 \mathrm{mg} . \mathrm{Nm}^{-3}$ at $13 \% \mathrm{O}_{2}$ for standard spruce pellets concern a pellet stove manufactured in 2007, which explains the quite high level obtained.

\section{Granulometric distribution on mass}

For the PM on mass (manual impactor) (Table 5 and Figure 1C), for all the pellets PM1 was the large majority. For CVP, the second granulometric fraction was $\mathrm{PM}>10 \mu \mathrm{m}$ whereas this fraction was

Table 4. Physico-chemical characteristic of the smoke from combustion of wood pellets and vineyard residues pellets.

\begin{tabular}{|c|c|c|c|c|c|c|c|c|c|}
\hline & & $\mathrm{O}_{2}(\%)$ & $\begin{array}{c}\mathrm{CO} \\
(\mathrm{ppm} \text { at } 13 \% \\
\left.\mathrm{O}_{2}\right)\end{array}$ & $\begin{array}{c}\mathrm{NOx} \\
(\mathrm{ppm} \text { at } 13 \% \\
\left.\mathrm{O}_{2}\right)\end{array}$ & $\begin{array}{c}\text { Smoke } \\
\text { temperature } \\
\left({ }^{\circ} \mathrm{C}\right)\end{array}$ & $\begin{array}{c}\text { Wood } \\
\text { consumption } \\
\left(\mathrm{kg} \mathrm{h}^{-1}\right)\end{array}$ & $\begin{array}{l}\text { Air } \\
\text { excess }\end{array}$ & $\begin{array}{l}\text { Combustion } \\
\text { conditions } \\
\text { and quality }\end{array}$ & $\begin{array}{c}\text { Efficiency } \\
(\%)\end{array}$ \\
\hline Standard & Spruce & 13.7 & 418 & 63 & 102 & 1.24 & 3 & Good & 84 \\
\hline Vineyard residues pellet & $\begin{array}{l}\text { OVP } \\
\text { CVP } \\
\text { Blend }\end{array}$ & $\begin{array}{l}15.5 \\
14.8 \\
16.1 \\
\end{array}$ & $\begin{array}{l}4530 \\
1470 \\
3780\end{array}$ & $\begin{array}{l}175 \\
218 \\
174\end{array}$ & $\begin{array}{c}110 \\
85 \\
107\end{array}$ & $\begin{array}{c}1.04 \\
1.07 \\
1.2\end{array}$ & $\begin{array}{l}>4 \\
>4 \\
>4\end{array}$ & $\begin{array}{c}\text { Acceptable } \\
\text { Degraded/poor } \\
\text { Acceptable }\end{array}$ & $\begin{array}{l}\text { na* } \\
\text { na } \\
\text { na* }\end{array}$ \\
\hline
\end{tabular}

OVP, organic vineyard pellets; CVP, common vineyard pellets; Blend, $50 \%$ of OVP and $50 \%$ CVP; na, not applicable. *The duration of the test was only of 30 min, after this time the combustion stopped because a large amount of ash has been formed, thus it was impossible to assess the efficiency (because it stopped); ${ }^{\circ}$ same than * but with a duration of 15 min due to the formation of very hard ashes in the combustion chamber.

Table 5. Characterisation of particulate physics and emissions from combustion of wood pellets and vineyard residues pellets.

\begin{tabular}{|c|c|c|c|c|c|c|c|c|c|c|}
\hline & \multicolumn{2}{|c|}{$\begin{array}{c}\mathrm{TSP} \\
\left(\mathrm{mg} \mathrm{Nm}^{-3}\right. \\
\left.\text { at } 13 \% \mathrm{O}_{2}\right)\end{array}$} & \multicolumn{4}{|c|}{$\begin{array}{c}\text { Manual impactor } \\
\text { (\% of granulometric fraction on the top; } \\
\text { emission factor in } \mathrm{mg} \mathrm{Nm}^{-3} \\
\text { at } 13 \% \mathrm{O}_{2} \text { on the bottom) }\end{array}$} & \multicolumn{4}{|c|}{ ELPI (granulometric fraction in \%) } \\
\hline Standard & Spruce & 98.6 & $\begin{array}{c}4.1 \% \\
2.0\end{array}$ & $\begin{array}{c}6.1 \% \\
3.0\end{array}$ & $\begin{array}{c}6.1 \% \\
3.0\end{array}$ & $\begin{array}{c}83.7 \% \\
40.3\end{array}$ & 0.0 & 0.1 & 40.3 & 59.5 \\
\hline $\begin{array}{l}\text { Vineyard } \\
\text { residues pellet }\end{array}$ & $\begin{array}{l}\text { OVP } \\
\text { CVP } \\
\text { Blend }\end{array}$ & $\begin{array}{r}256.3 \\
44.4 \\
210.5\end{array}$ & $\begin{array}{c}0.0 \% \\
0.0 \\
19.0 \% \\
17.3 \\
0.8 \%\end{array}$ & $\begin{array}{c}3.9 \% \\
5.2 \\
7.1 \% \\
6.5 \\
2.3 \%\end{array}$ & $\begin{array}{c}2.5 \% \\
3.2 \\
9.5 \% \\
8.7 \\
6.2 \%\end{array}$ & $\begin{array}{c}93.6 \% \\
123.0 \\
64.3 \% \\
58.4 \\
90.7 \%\end{array}$ & $\begin{array}{l}0.0 \\
\text { na* } \\
0.0\end{array}$ & $\begin{array}{c}0.2 \\
\text { na* } \\
0.2\end{array}$ & $\begin{array}{l}60.4 \\
\text { na* } \\
64.4\end{array}$ & $\begin{array}{l}39.4 \\
\text { na* } \\
35.4\end{array}$ \\
\hline
\end{tabular}

TSP, total suspended particles; ELPI, electrical low pressure impactor; PM, particulate matter; OVP, organic vineyard pellets; CVP, common vineyard pellets; Blend, 50\% of OVP and 50\% CVP; na, not applicable. *It was impossible to maintain the combustion long enough to realize this measurement. 
around 0 for all the other pellets. This is related to some flying ashes, and, since the ash was really hard, flying ashes created bigger particles (Osán et al., 2002). There was not real difference for the granulometric fraction in mass between OVP, Blend and spruce pellets. However, the emission factor of PM1 was three times more important in the case of OVP and Blend pellets (123 and 141 mg. $\mathrm{Nm}^{-3}$ at $13 \% \mathrm{O}_{2}$ ) than for spruce $\left(40 \mathrm{mg} \cdot \mathrm{Nm}^{-3}\right.$ at $13 \% \mathrm{O}_{2}$ ). For other granulometric fractions, it was similar with an average of 5 mg. $\mathrm{Nm}^{-3}$ at $13 \% \mathrm{O}_{2}$.

\section{Granulometric distribution in number}

In number (Figure 1D), PM emitted during combustion of vineyard-based pellet differed from wood based pellets principally for the submicron PM1. The main fraction $(59.50 \%)$ of total dust emissions of wood pellets was PM 0.1 while the main fraction of OVP and Blend $(60.41 \%$ and $64.38 \%$ respectively) was represented by the PM 0.1-1.0. Some particle emissions can be correlated to the ash content of the fuel and to some elements contents as alkaline metals, S, Cl and Zn (Carvalho et al., 2013; Obernberger et al., 2006). Here, the hardness of the ash countered this possible effect but increased the main size of particles in number. This conclusion is already now available for the mass concentration, but this phenomenon could happen on PM1 and then it is not visible with the analyser used.

The pellets need to be improved (mainly concerning the ash content) to realise some longer test and get more exhaustive results. Furthermore, the design of the stove chamber is not optimal for vineyard-based fuel, an excess of ash is forming, the excess of air is not optimal.

\section{Conclusions}

In this study, an exhaustive characterisation of vineyard-based pellets has been made. Pellets quality has been assessed following the in force European and International standard and a combustion test has been performed in a domestic pellet stove. The purpose of this research work was to determine if the vineyard-based pellet as they are could be used in domestic appliances and to identify the weak points of this potential biofuel to define its future developments. Three vineyard-based pellets have been manufactured: one from organic managed vineyard residues, one from common managed vineyard residues and a blend pellet made from both vineyard residues. The results have been then compared to a commercial spruce pellet. Vineyard based-pellets do not satisfy the European and International legal requirements for a type B wood pellet because of their high ash content $(>2 \%)$ and the low durability of blend pellets $(<96.5 \%)$ but they meet the specifications for a type $\mathrm{B}$ non-woody pellets. The elemental analysis reveals a content of $\mathrm{Cu}$ higher than the standard limit ( $>10 \mathrm{ppm})$ and the $\mathrm{S}$ content of the common managed vineyard pellets is equal to the maximum value allowed by the EN ISO standard for wood pellets. Nitrogen content of vineyard-based pellets is high but still included within the standard limits.

The combustion test achieved at laboratory scale highlights many issues related to the use of vineyard-based pellets in domestic stove: i) the ash fills the combustion chamber very fast and it was impossible to keep on the tests for $1 \mathrm{~h}$; ii) during CVP combustion, the really hard ash formed in the combustion chamber limits the reaction of combustion and the TSP assessment; iii) to burn vineyard-based pellets, a lot of air was injected that it means a
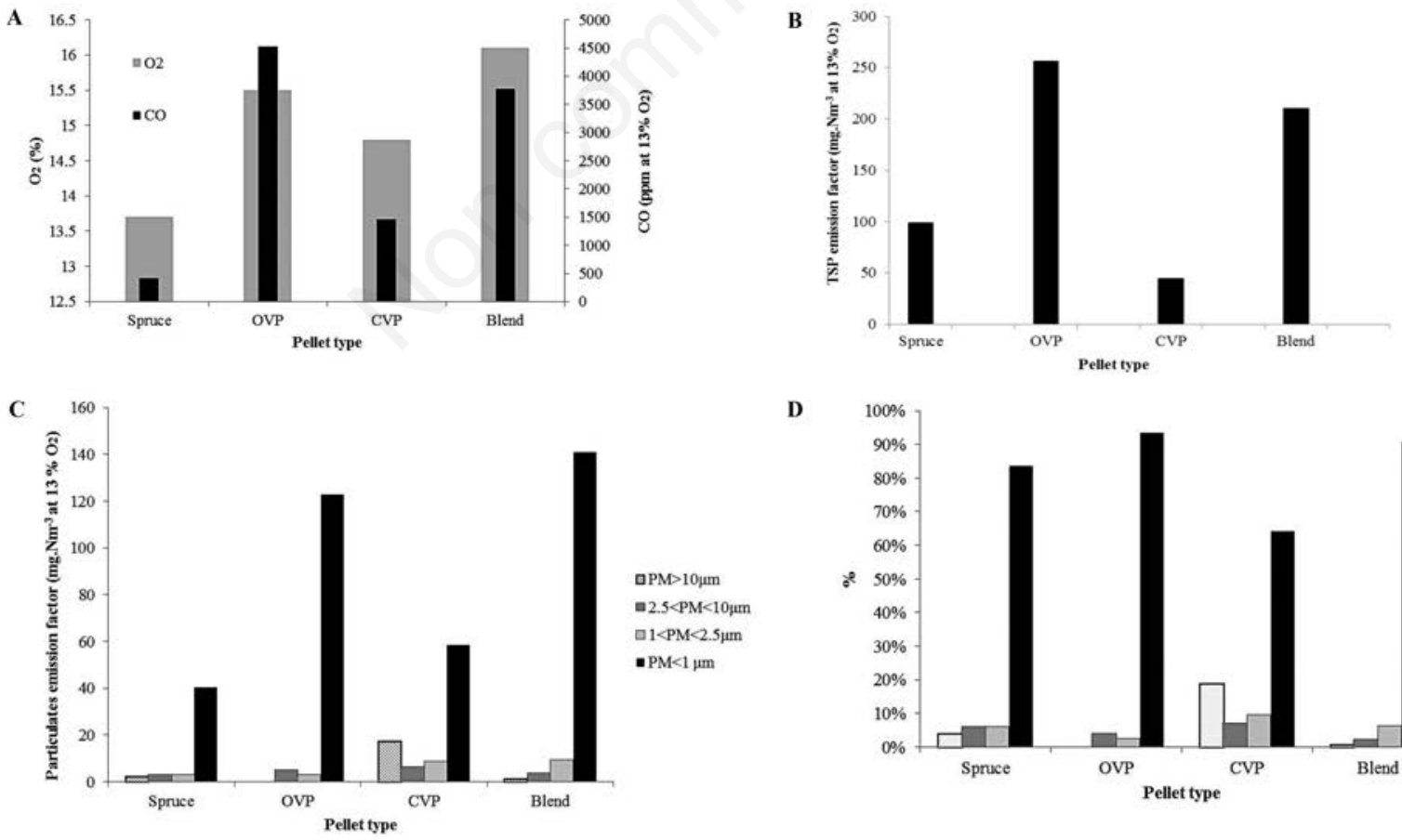

D

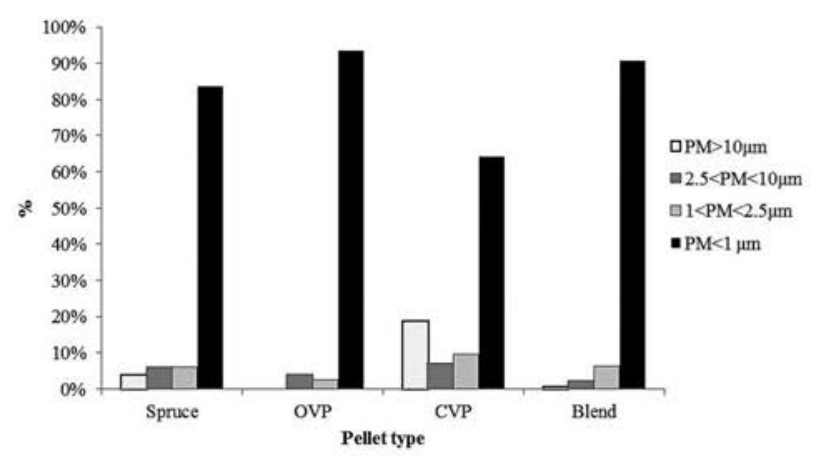

Figure 1. Analysis of the smoke produced from the combustion of pellets: A) percentage of $\mathrm{O}_{2}$ and $\mathrm{CO}$; B) total suspended particles bution on mass. OVP, organic vineyard pellets; CVP, common vineyard pellets; blend, $50 \%$ of OVP and $50 \%$ CVP. 
colder combustion and some higher pollutant emissions. As expected, the vineyard-based pellet $\mathrm{NO}_{\mathrm{x}}$ emissions were more than double the emission control. CVP showed the higher $\mathrm{NO}_{\mathrm{x}}$ emissions but the lower emissions measured for OVP and Blend pellets are related to the high $\mathrm{CO}$ emissions that inhibit $\mathrm{NO}_{\mathrm{x}}$ formation. Moreover, the airflow settings should be at least discussed with pellet stove manufacturers in order to use vineyard-based pellets in order to guarantee better combustion conditions.

The manual impactor measurements showed that PM1 is the larger emitted fraction in all the tested pellets. For CVP, the second granulometric fraction is $\mathrm{PM}>10 \mu \mathrm{m}$ whereas this fraction is around 0 for all the other pellets. This is related to some flying ashes, and, since the ash is really hard, flying ash create big particles. However, the emission factor of PM1 is three times more important in the case of OVP and Blend pellet (123 and $141 \mathrm{mg} \cdot \mathrm{Nm}^{-3}$ at $13 \% \mathrm{O}_{2}$ ) than spruce pellet ( $40 \mathrm{mg} . \mathrm{Nm}^{-3}$ at $13 \% \mathrm{O}_{2}$ ). Furthermore additional consideration have emerged from the comparison of vineyard-based pellets technical features with the specifications of non-woody pellets. Namely, the vineyard residues pellets are more similar to agricultural biomass than woody biomass because of the fito-chemical and fertilisation treatments used in the vineyards. This could be the reason why the vineyard residues meet the specifications of type $B$ standard for non-woody pellets (ISO, 2014c). Further studies need to be performed to make the vineyard based biomass available to produce energy in domestic stoves, working specially on pellet formulations (i.e., mixing wood and vineyard biomass) to reduce the variability and the influence of fito-chemical and fertilisation treatments, and on designing special pellet stoves to burn this kind of biomass.

\section{References}

AEBIOM. 2015. European Bioenergy outlook 2015 - Statistical report. Brussels.

Badocco D., Lavagnini I., Mondin A., Tapparo A., Pastore P. 2015. Limit of detection in the presence of instrumental and noninstrumental errors: study of the possible sources of error and application to the analysis of 41 elements at trace levels by ICP-MS technique. Spectrochim. Acta B 107:178-84.

Bentley R.W., Mannan S.A., Wheeler S.J. 2007. Assessing the date of the global oil peak: The need to use $2 \mathrm{P}$ reserves. Energ. Policy 35:6364-82.

Carone M.T., Pantaleo A., Pellerano A. 2011. Influence of process parameters and biomass characteristics on the durability of pellets from the pruning residues of Olea europea L. Biomass Bioener. 35:402-10.

Carvalho L., Wopienka E., Pointner C., Lundgren J., Verma V.K., Haslinger W., Schmidt C. 2013. Performance of a pellet boiler fired with agricultural fuels. Appl. Energ. 104:286-96.

Cherney J.H., Verma V.K. 2013. Grass pellet Quality Index: A tool to evaluate suitability of grass pellets for small scale combustion systems. Appl. Energ. 103:679-84.

Chico-Santamarta L., Chaney K., Godwin R.J., White D.R., Humphries A.C. 2012. Physical quality changes during the storage of canola (Brassica napus L.) straw pellets. Appl. Energ. 95:220-6.

Dhamodaran A., Afzal M. 2012. Compression and springback properties of hardwood and softwood pellets. BioResour. 7:4362-76.

Dias J., Costa M., Azevedo J.L.Y. 2004. Test of small domestic boiler using different pellets. Biomass Bioener. 27:531-9.

Duca D., Toscano G., Pizzi A., Rossini G., Fabrizi S., Lucesoli G.,
Servili A., Mancini V., Romanazzi G., Mengarelli C. 2016. Evaluation of the characteristics of vineyard pruning residues for energy applications: effect of different copper-based treatments. J. Agr. Eng. 47:22-7.

Dunnet A.J., Shah N. 2007. Prospects for bioenergy. J. Biobased Mater. Bioener. 1:1-18.

Dwivedi P., Khanna D., Bailis M., Ghilardi A. 2014. Potential greenhouse gas benefits of transatlantic wood pellet trade. Environ. Res. Lett. 9:024007.

García-Maraver A., Popov V., Zamorano M. 2011. A review of European standards for pellet quality. Renew. Energy 36:3537-40.

Garijo E.G., Jensen A.D., Glarborg P. 2003. Kinetic study of NO reduction over biomass char under dynamic conditions. Energy Fuels 17:1429-36.

Gil M.V., Oulego P., Casal M.D., Pevida C., Pis J.J., Rubiera F. 2010. Mechanical durability and combustion characteristics of pellets from biomass blends. Bioresour. Technol. 101:8859-67.

Hanlon P., McCartney G. 2008. Peak oil: Will it be public health's greatest challenge? Public Health 122:647-52.

Hu Q., Shao J., Yang H., Yao D., Wang X., Chen H. 2015. Effects of binders on the properties of bio-char pellets. Appl. Energ. 157:508-16.

IEA (International Energy Agency). 2015. $\mathrm{CO}_{2}$ emissions from fuel combustion; 2015 Edition. Available from: http://www.iea.org/Accessed: July 2016.

ISO. 2014a. Norm ISO 17225-1:2014. Solid biofuel. Fuel specifications and classes. Part 1: General requirements. International Organisation for Standardisation Publ., Geneva, Switzerland.

ISO. 2014b. Norm ISO 17225-2:2014. Solid biofuel. Fuel specifications and classes. Part 2: Graded wood pellets. International Organisation for Standardisation Publ., Geneva, Switzerland.

ISO. 2014c. Norm ISO 17225-6:2014. Solid biofuels. Fuel specifications and classes. Part 6: Graded non-woody pellets. International Organisation for Standardisation Publ., Geneva, Switzerland.

ISTAT (Italian National Statistical Institute). 2014. $6^{\text {th }}$ General census of agriculture. Available from: http://censimentoagricoltura.istat.it Accessed: May 2016.

Kaliyan N., Morey R.V. 2009. Factors affecting strength and durability of densified biomass products. Biomass Bioener. 33:337-59.

Kavargiris S.E., Mamolosa A.P., Constantinos A., Tsatsarelis C.A., Nikolaidou A.E., Kalburtji K.L. 2009. Energy resources' utilisation in organic and conventional vineyards: energy flow, greenhouse gas emissions and biofuel production. Biomass Bioener. 33:1239-50.

Larsson S.H., Rudolfsson M. 2012. Temperature control in energy grass pellet production - Effects on process stability and pellet quality. Appl. Energ. 97:24-9.

Lehman B., Schröder H.W., Wollenberg R., Repke J.U. 2012. Effect of miscanthus addition and different grinding processes on the quality of wood pellets. Biomass Bioener. 44:150-9.

Lehtikangas P. 2001. Quality properties of pelletised sawdust, logging residues and bark. Biomass Bioener. 20:351-60.

Liu Z., Quek A., Balasubramanian R. 2014. Preparation and characterisation of fuel pellets from woody biomass, agro-residues and their corresponding hydrochars. Appl. Energ. 113:1315-22.

Mcginn D., Green D., Hinrichs-Rahlwes R., Sawyer S., Sander M., Taylor R., Giner-Reichl I., Teske S., Lehmann H., Hales D. 2013. REN21 2013 Global status report. Paris, France. Available from: http://www.ren21.net/ Portals/0/documents/ Resources/ GSR/ 2013/GSR2013_lowres.pdf

Mediavilla I., Fernández M.J., Esteban L.S. 2009. Optimisation of palletisation and combustion in a boiler of $17.5 \mathrm{~kW}$ th for vine 
shots and industrial cork residue. Fuel Process. Technol. 90:621-8.

Miranda M.T., Arranz J.I., Rojas S., Montero I., López M., Cruz J.A. 2011. Characterisation of grape pomace and pyrenean oak pellet. Fuel Process. Technol. 92:278-83.

Nunes LJR, Matias JCO, Catalão JPS. 2014. Mixed biomass pellets for thermal energy production: A review of combustion models. Appl Energ 127:135-40.

Obernberger I., Biedermann F., Widmann W., Riedl R. 1997. Concentrations of inorganic elements in biomass fuel and recovery in the different ash fractions. Biomass Bioener. 12:211-24.

Obernberger I., Brunner T., Bärnthaler G. 2006. Chemical properties of solid biofuels - significance and impact. Biomass Bioener. 30:973-82.

Obernberger I., Thek G. 2004. Physical characterisation and chemical composition of densified biomass fuels with regards to their combustion behaviour. Biomass Bioener. 27:633-69.

Osán J., Alföldy B., Török S., Van Grieken R. 2002. Characterisation of wood combustion particles using electron probe microanalysis. Atmospheric Environ. 36:2207-14.

Pastircakova K. 2004. Determination of trace metal concentrations in ashes from various biomass material. Energy Education Technol. 13:97-104.

Picchi G., Silvestri S., Cristoforetti A. 2013. Vineyard residues as a fuel for domestic boilers in Trento Province (Italy): comparison to wood chips and means of polluting emission control. Fuel 113:43-9.

Pierobon F., Zanetti M., Grigolato S., Sgarbossa A., Anfodillo T., Cavalli R. 2015. Life cycle environmental impact of firewood production - A case study in Italy. Appl. Energ. 150:185-95.

Pöyry. 2011. Pellets - Becoming a global commodity? Perspective on the global pellet market to 2020. View point report, Pöyry Vantaa, Finland. Available from: http://www.poyry.co.uk/sites/ www.poyry.co.uk/files/110.pdf

Provenzano M.R., El Bilali H., Simeone V., Baser N., Mondelli D., Cesari G. 2012. Copper contents in grapes and wines from a Mediterranean organic vineyard. Food Chem. 122:1338-43.

Regione Veneto. 2012. Le superfici agricole in Veneto. Veneto tendenze 3/2012. Available from: http://www.consiglioveneto.it/ crvportal/upload_crv/serviziostudi/1372949054823_Veneto_T endenze3 2012.pdf Accessed: May 2016.

Saidur R., Abdelaziz E.A., Demirbas A., Hossain M.S., Mekhilef S. 2011. A review on biomass as a fuel for boilers. Renew. Sustain. Energy Rev. 15:2262-89.

Sgarbossa A., Costa C., Menesatti P., Antonucci F., Pallottino F., Zanetti M., Grigolato S., Cavalli R. 2014. Colorimetric patterns of wood pellets and their relations with quality and energy parameters. Fuel 137:70-6.

Sgarbossa A., Costa C., Menesatti P., Antonucci F., Pallottino F., Zanetti M., Grigolato S., Cavalli R. 2015. A multivariate SIMCA index as discriminant in wood pellet quality assessment. Renew. Energy 6: 258-63.

Spinelli R., Nati C., Mescalchin E., Magagnotti N. 2012. Production and quality of biomass fuel form mechanised collection. Appl. Energ. 89:374-79.

Stelte W., Sanadi A.R., Shang L., Holm J.K., Ahrenfeldt J., Henriksen U.B. 2012. Recent developments in biomass pelletization - a review. BioResour. 7:4451-90.

Tariba B. 2011. Metals in wine - impact on wine quality and health outcomes. Biol. Trace Element Res. 144:143-56.
Toscano G., Riva G., Foppa Pedretti E., Corinaldesi F., Mengarelli C., Duca D. 2013. Investigation on wood pellet quality and relationship between ash content and the most important chemical elements. Biomass Bioener. 56:317-22.

UNI (Ente Italiano di Normazione). 2006. Residential space heating appliances fired by wood pellets - Requirements and test methods. Norm UNI EN 14785:2006. UNI, Milano-Roma, Italy.

UNI (Ente Italiano di Normazione). 2009a. Norm UNI EN $14474-$ 1:2009. Solid biofuels. Determination of moisture content. Oven dry method. Part 1: total moisture e reference method. UNI, Milano-Roma, Italy.

UNI (Ente Italiano di Normazione). 2009b. Norm UNI EN 14918:2009. Solid biofuels. Determination of calorific value. UNI, Milano-Roma, Italy.

UNI (Ente Italiano di Normazione). 2009c. Norm UNI EN 15103:2009. Solid biofuels. Determination of bulk density. UNI, Milano-Roma, Italy.

UNI (Ente Italiano di Normazione). 2009d. Norm UNI EN 152101:2009. Solid biofuels. Determination of mechanical durability of pellets and briquettes. Part 1: Pellets. UNI, Milano-Roma, Italy.

UNI (Ente Italiano di Normazione). 2010. Norm UNI EN 14775:2010. Solid biofuels. Determination of ash content. UNI, Milano-Roma, Italy.

UNI (Ente Italiano di Normazione). 2011a. Norm UNI EN 14780:2011. Solid biofuels e sample preparation. UNI, Milano-Roma, Italy.

UNI (Ente Italiano di Normazione). 2011b. Norm UNI EN 149612:2011. Solid biofuels. Fuel specifications and classes. Part 2: wood pellets for non-industrial use. UNI, Milano-Roma, Italy.

UNI (Ente Italiano di Normazione). 2011c. Norm UNI EN 15104:2011. Solid biofuels. Determination of total content of carbon, hydrogen and nitrogen. Instrumental methods. UNI, Milano-Roma, Italy.

UNI (Ente Italiano di Normazione). 2011d. Norm UNI EN 15289:2011. Solid biofuels. Determination of total content of sulfur and chlorine. UNI, Milano-Roma, Italy.

UNI (Ente Italiano di Normazione). 2011e. Norm UNI EN 15290:2011. Solid biofuels. Determination of major elements $\mathrm{Al}, \mathrm{Ca}, \mathrm{Fe}, \mathrm{Mg}, \mathrm{P}, \mathrm{K}, \mathrm{Si}, \mathrm{Na}$ and Ti. UNI, Milano-Roma, Italy.

UNI (Ente Italiano di Normazione). 2011f. Norm UNI EN 15297:2011. Solid biofuels. Determination of minor elements. As, $\mathrm{Cd}, \mathrm{Co}, \mathrm{Cr}, \mathrm{Cu}, \mathrm{Hg}, \mathrm{Mn}, \mathrm{Mo}, \mathrm{Ni}, \mathrm{Pb}, \mathrm{Sb}, \mathrm{V}$ and $\mathrm{Zn}$. UNI, Milano-Roma, Italy.

Van Loo S., Koppejan J. 2008. Handbook of biomass combustion and co-firing. Earthscan, London, UK.

Vassilev S.V., Baxter D., Andersen L.K., Vassileva C.G. 2010. An overview of the chemical composition of biomass. Fuel 89:913-33.

Velázquez-Martí B., Fernández-González E., López-Cortés I., Salazar-Hernández D.M. 2011. Quantification of the residual biomass obtained from pruning of vineyards in Mediterranean area. Biomass Bioener. 35:3453-64.

Verma V.K., Bram S., Delattin F., Laha P., Vandendael I., Hubin A., De Ruyck J. 2012. Agro-pellets for domestic heating boilers: Standard laboratory and real life performance. Appl. Energ. 90:17-23.

Werkelin J., Skrifvars B.J., Zevenhoven M., Holmbom B., Hupa M. 2010. Chemical forms of ash-forming elements in woody biomass fuels. Fuel 89:481-93. 